九州大学学術情報リポジトリ

Kyushu University Institutional Repository

\title{
The Socio-Economic Analys is of Contracted Turkey Farms : The Turkish Case
}

Dellal, Ilkay

Agricultural Economics Research Institute of Turkey, Ankara

Kai, Satoshi

Laboratory of Agricultural Marketing, Division of Industrial Organization of

Agribusiness, Department of Agricultural and Resoruce Economics, Faculty of Agriculture, Kyushu University

Tan, Sibel

Agricultural Economics Research Institute of Turkey, Ankara

Tan, Sami

Department of Economics, University of Dokuz Eylul

https://doi.org/10.5109/4611

出版情報: 九州大学大学院農学研究院紀要. 49 (2)，pp.513-524，2004-10-01. Faculty of Agriculture, Kyushu University

バージョン：

権利関係 : 


\title{
The Socio-Economic Analysis of Contracted Turkey Farms: The Turkish Case
}

\author{
Ilkay DELLAL', Satoshi KAI*, Sibel TAN ${ }^{1}$ and Sami TAN ${ }^{2}$ \\ Laboratory of Agricultural Marketing, Division of Industrial Organization of Agribusiness, \\ Department of Agricultural and Resource Economics, Faculty of Agriculture, \\ Kyushu University, Fukuoka 812-8581, Japan \\ (Received April 9, 2004 and accepted July 13, 2004)
}

\begin{abstract}
This study was examined socio economic characteristics of contracted turkey farms in Turkey. Results reveal that young labor force and literacy rate were at sufficient level. Although main production activity on farms was contracted turkey breeding, plant production, cattle, sheep and goats breeding were other activities carried out. While $83.98 \%$ of farm land under farm property, $16.02 \%$ of that was used as rented and shared land. Grain production had the highest share in plant production. The number of turkeys, large and small animals was, respectively $4845,3.38$ and 0.32 heads in average farm. Tractors were present on $40.82 \%$ of farms. While the share of variable cost in production cost was $62.54 \%$, the share of fixed cost was $37.46 \%$ in production cost. The highest shares in variable cost, respectively, belong to heating $(16.51 \%)$, lightening $(15.87 \%)$ and pad $(12.11 \%)$ cost. On the other hand, the highest shares in fixed cost, respectively, belong to poultry-house depreciation $(10.17 \%)$, poultry-house interest (10.17\%) and permanent labor expenses (6.81\%). Gross production value, gross income, and net income were, respectively, found as $6428.35 \$ /$ year, 3083.18/year and $1293.91 \$$ year. Duration of contracted turkey breeding of farms was on average 2.63 periods. The most important factors causing to run a contracted turkey firm was price and sale guarantee. However, not having any influence in determining buying price of turkeys was the most important problem of farms. Even though $63.27 \%$ of farms were not satisfied income obtained from turkey breeding, $83.67 \%$ of farms stated that they will have maintained turkey breeding due to guaranteed income depending on marketing guarantee and input provision.
\end{abstract}

\section{INTRODUCTION}

Although different methods are used at providing vertical integration between industrial and commercial parts of agriculture, the most prevailing method on this matter is contracted production model. Contracted production model, made between farms and producers before sowing, planting and production, refers to production and marketing model in which farmer take responsibility of realizing certain crop area and production in return farms guarantees buying product under certain conditions. Contracted production model includes four stages namely: input provision, production, processing and marketing (Ozcelik et al., 1999).

Contracted production model is used in developed countries for a long time. This model used, firstly, in the $19^{\text {th }}$ century in Japan on nondurable products such as peach and sugar beet. Contracted production model have used, increasingly, fattening livestock,

\footnotetext{
1 Agricultural Economics Research Institute of Turkey, Ankara

2 Department of Economics, University of Dokuz Eylul, Izmir

* Corresponding Author (E-mail: satokai@agr.kyushu-u.ac.jp)
} 
broiler, milked livestock, sugar beet and sugar can since 1960s. Importance of contracted production model gradually increases and contracted production model plays an important role at liberalizing of markets and overcoming commercial obstacles between industrialist and breeder (Rehber, 2000). There is a vast on vertical integration in the world (Salinger, 1988; Hart and Trole, 1990; Ordover et al., 1990; Riordan, 1998; Ozcelik et al., 1999; Rehber, 2000; Warning and Nicel, 2000; Hackner, 2001) which argued whether economic or social impacts both country and farm level like as competitiveness, welfare effects, economic returns to farms etc.

Contracted agricultural practices in Turkey has taken place since 1960s and the first successful example realized in sugarbeet production. In addition, this kind of practices have used in seed producing, greenhouse tomato production, corn production, floriculture and broiler. One of areas in which contracted turkey production getting increase by degrees is turkey breeding.

Turkey breeding in Turkey was, fundamentally, made by extensive system with traditional methods in small family farms. Turkey race in this production system is American bronze, grazing in pasture, stubble, and fallowing areas about 8-9 months and marketed for consumption in the beginning of new year, mainly. On the other hand, vertical integration in turkey production has gone up with increasing turkey consumption since 1995 and this has made industrialists meeting their turkey production needs from farmers. Therefore, important developments have occurred in contracted turkey breeding. Contracted turkey breeding has, increasingly, prevailed in certain regions due to opportunities provided by firms such as technology and input provision, sale and price guarantee and creating employment. As to 2000 statistics, there were 4 integrated firms working on turkey breeding and these firms supplied turkey meat by contracted with 400 farms that made intensive turkey breeding According to the same data, this type production model meets $93 \%$ of total turkey production. Economic crises experienced in recent periods has put undesirable effects on agricultural firms and especially on small family farms, so some farms has tended to dairy production, apiculture, angora rabbit breeding, milked goat, quail breeding and contracted turkey breeding in order to increase and keep on their incomes. On the other hand, analyses determining economic efficiency have not carried out at expected level in all activities mentioned above except dairy production, so efficient policies have not produced. Therefore, this study aims at analyzing socio-economic characteristics of contracted turkey farms, determining problems and expectations, and finding solutions to increase incomes from contracted turkey breeding in the light of data obtained.

\section{MATERIAL AND METHOD}

\section{Turkey Production Systems Definitions}

Extensive Turkey Production (Conventional): extensive type turkey production in Turkey are, mainly, made by small family firms to meet turkey consumption in the new year celebrations. These farms buy turkey chicks from private and public firms between April $1^{\text {st }}$ and May $15^{\text {th }}$. Chicks are raised in rearing poultry houses about 1-2 months. Later, they are grazed in pasture, stubble and fallowing areas during daytime until they are marketed. Poultry houses of these farms are established in the courtyard of farms 
or/and outside. While feed grains are not given during grazing, both feed grains, including purchased grains, and household wastes are given during night. Reaching about 7-8 kg of turkeys are marketed as mostly alive for the New. Year celebration. All the economic activities in these farms are managed by farmers.

Contracted Turkey Production: There is two different systems in contracted turkey farms. The first of them is to breed turkey chicks by contracted farmers specialized on raising chicks during 6 weeks. At the end of the period, turkey chicks become turkey ducklings and they are taken by firms and given other farmers who specialized on turkey fattening. That second system is to fatten turkey ducklings, raised by first system. Breeders do not take fledgling turkeys out they fatten them in their poultry houses about 18 weeks, instead. At the end of the fattening period, turkeys are slaughtered in the slaughterhouses of integrated system and then they are marketed. Poultry houses belong to breeders and bulk of inputs and marketing are met by firms in both two systems. In this study the second type of contracted turkey farms was examined.

\section{Research Region}

There are, basically, 4 integrated turkey firms in Turkey and these firms are located in Bolu province in West Black Sea Region, Izmir, Manisa and Aydın provinces in Aegean Region, and Van province in East Anatolia Region. The integrated firms is making contract in the farms in their region. So, these regions are chosen as research region.

\section{Sampling and Data Collection}

In this study, all the contracted farms of integrated firms in Turkey were constituted main population. $20 \%$ of this population was selected as sample farms and 38 farms were taken into consideration. Primary data were obtained by face-to-face surveys with contracted breeders in 2002 and data was belong to 2001 production year. Secondary data were obtained from SIS (State Statistics Institute), SPO (State Planning Organization), and MARA (Ministry of Agriculture and Rural Affairs).

\section{Criteria of Economic Analysis}

When calculating labor resource in the farms, Male Labor force Unit (MLU) was used. Family Population was expressed in terms of MLU by taking into consideration work capability in respect of age and gender.

In economic analysis of farms, Gross Production Value (GPV), Gross Income (GI), Net Income (NI), Fixed Costs and Variable Costs were calculated. GPV was obtained by multiplying total live weight with product price. Total costs were obtained by adding fixed cost with variable cost. GI was calculated by subtracting variable cost from GPV, NI was calculated by subtracting Total Costs from GPV.

\section{RESULTS AND DISCUSSION}

\section{Some socio-economic characteristics}

In the contracted turkey farms, the population and labor resource as to age groups and gender was given on Table 1. Total individual number was 4.43 and male population 
Table 1. Population and labor force of farms.

\begin{tabular}{|c|c|c|c|c|c|c|c|c|}
\hline \multirow{2}{*}{$\begin{array}{l}\text { Age } \\
\text { Groups }\end{array}$} & \multicolumn{4}{|c|}{ Population } & \multicolumn{4}{|c|}{ Labor (MLU)* } \\
\hline & Male & Female & Total & $\%$ & Male & Female & Total & $\%$ \\
\hline $0-6$ & 0.28 & 0.14 & 0.38 & 8.76 & - & - & - & - \\
\hline $7-14$ & 0.38 & 0.24 & 0.61 & 14.06 & 0.28 & 0.12 & 0.40 & 12.30 \\
\hline $15-49$ & 1.59 & 1.30 & 2.89 & 64.06 & 1.51 & 0.95 & $\therefore .46$ & 76.18 \\
\hline $50-+$ & 0.27 & 0.27 & 0.54 & 13.13 & 0.26 & 0.11 & $0: 37$ & 11.52 \\
\hline TOTAL & 2.41 & 1.95 & 4.43 & 100 & 2.05 & 1.18 & 3.23 & 100,00 \\
\hline
\end{tabular}

* coefficients used at forming MLU were taken as 0.5 both male and female in 7-14 age group, as 1.0 for . male and 0.75 for female in $15-49$ age group, as 0.75 for male and 0.50 for female in 50 and higher ages.

was higher than female population. Individuals aged 15-49 were higher than others and constituted $64.06 \%$ of total population in family. When Family labor force was calculated, population, age and gender were defined in terms of male labor unit. As to this, 3.23 man labor units exist in contracted turkey farms and $76 \%$ of that was in 15-49 age group. Therefore, labor force obtained from each family was at the sufficient level.

\section{Educational Status}

As shown on Table 2 literacy rate in contracted turkey breeding farms was $95.85 \%$. This rate was above Turkey average $(80.46 \%)$ (SIS, 2001) whereas literacy rate among male was $(99.07 \%)$, that of is $91.76 \%$ among female. Therefore literacy:rate of male group was higher than female group. $43.52 \%, 18.65 \%, 22.77 \%$ and $9.84 \%$ of farm population are, respectively, primary school, secondary school, high school and university graduate. As compare to average education level in rural areas in Turkey; it could be said that the education level in contracted farms was higher than average (SIS, 2001)

Table 2. Educational status on farms (\%).

\begin{tabular}{lccccccc}
\hline & Illiterate & $\begin{array}{c}\text { Only } \\
\text { literate }\end{array}$ & $\begin{array}{c}\text { Primary } \\
\text { School }\end{array}$ & $\begin{array}{c}\text { Middle } \\
\text { School }\end{array}$ & $\begin{array}{c}\text { High } \\
\text { School }\end{array}$ & .. University & Total \\
\hline Male & 0.93 & 0.93 & 35.19 & 27.78 & 24.07 & 11.10 & 100.00 \\
Female & 8.24 & 3.53 & 54.12 & 7.06 & 18.82 & 8.23 & 100.00 \\
\hline Total & 4.15 & 2.07 & 43.52 & 18.65 & 21.77 & 9.84 & 100.00 \\
\hline
\end{tabular}

\section{Some Social Characteristics of Farm Managers}

In the studied farms, all farm managers were male and also married. Average age was 42.92 and education period was 7.76 year. TV and radio watching rate was over $95 \%$. Agricultural programs watching rate was at the medium level, but regular newspaper reading rate was at the low level. However, these numbers were quite good for rural areas. 
Table 3. Some social characteristics of farm managers.

\begin{tabular}{ll}
\hline Some Social Characteristics & \\
\hline Marital status & All married \\
Life expectancy (year) & 42.92 \\
Average education (year) & 7.76 \\
TV and radio watching (\%) & 95.92 \\
Agricultural programs watching (\%) & 69.39 \\
Regular newspaper reading (\%) & 42.86 \\
\hline
\end{tabular}

\section{Organizational Situation and Relations with Banks}

The studied farms were not organized at a good level. These farms engaged in turkey breeding did not have organizations such as cooperatives, association, union etc. Low organizational level, generally, stems from lack of agricultural organization in Turkey. However, $36.73 \%, 46.94 \%$ and $6.12 \%$ of farms were, respectively, have membership to a cooperative, the Turkish Farmers Union and any association. Nonetheless, these rates were over Turkey average. Reason for this was that educational level of turkey breeding farms was higher than other farms, respectively. In addition, Farms' working situations with banks were at the medium level (see Table 4).

Table 4. Organizational situation and relations with banks.

\begin{tabular}{lr}
\hline Organizational level & $\%$ \\
\hline Cooperative & 36.73 \\
Association & 46.94 \\
Society & 6.12 \\
Farms working with banks & 48.98 \\
Farms not working with banks & 51.02 \\
\hline
\end{tabular}

\section{Economic Characteristics}

Although main activity of contracted turkey breeding farms was intensive turkey breeding, these farms also were engaged in plant and other animal production activities. Therefore, information with other agricultural activities was given following parts.

\section{The Land}

Farms' land area included own land and share land and rented land. Land area on turkey breeding farms was on the average 27.84 decares (see Table 5). While $83.98 \%$ of farms' land area was owned land, 16.02 of that was managed by shared and rented land. Average parcel number was 2.68 .

Crop pattern of farm

Contracted turkey farms were, mainly, engaged in grain production in terms of plany production (see Table 6). As a matter of fact, $48.89 \%, 15 \%, 6.16 \%$ and $1.36 \%$ of farm land was allocated to wheat, barley, corn and oat production. Fallow land area was $17.42 \%$. Livestock on farms

As shown on Table 7, number of turkeys bred on agricultural farms under contracted turkey breeding was on the average 4845 heads. On the other hand, $34.33 \%$ of farms not only had turkey but also had sheep and goats. As large ruminant animals, cattle was kept, 
Table 5. Farms' land area and Possession Type:

\begin{tabular}{|c|c|c|c|c|}
\hline Land Possession Type & Land type & $\%$ & $\mathrm{Da}$ & $\%$ \\
\hline Own land & $\begin{array}{l}\text { Area sown } \\
\quad \text { Dry } \\
\quad \text { Irrigated } \\
\text { Fruits } \\
\text { Vegetables } \\
\text { Meadow } \\
\text { Other } \\
\text { Total }\end{array}$ & 83.98 & $\begin{array}{r}16.64 \\
11.86 \\
4.78 \\
5.68 \\
0.11 \\
0.95 \\
0.00 \\
23.38\end{array}$ & $\begin{array}{r}71.17 \\
50.73 \\
20.44 \\
24.29 \\
0.47 \\
4.06 \\
0.00 \\
100.00\end{array}$ \\
\hline $\begin{array}{l}\text { Shared and rented } \\
\text { land }\end{array}$ & $\begin{array}{l}\text { Area sown } \\
\quad \quad \text { Dry } \\
\quad \text { Irrigated } \\
\text { Fruits } \\
\text { Vegetables } \\
\text { Meadow } \\
\text { Other } \\
\text { Total }\end{array}$ & 16.02 & $\begin{array}{l}3.16 \\
3.05 \\
0.11 \\
1.30 \\
0.00 \\
0.00 \\
0.00 \\
4.46\end{array}$ & $\begin{array}{r}70.85 \\
68.39 \\
2.47 \\
29.15 \\
0.00 \\
0.00 \\
0.00 \\
100.00\end{array}$ \\
\hline Farm land & $\begin{array}{l}\text { Area sown } \\
\quad \text { Dry } \\
\quad \text { Irrigated } \\
\text { Fruits } \\
\text { Vegetables } \\
\text { Meadow } \\
\text { Other } \\
\text { Total }\end{array}$ & 100.00 & $\begin{array}{r}19.80 \\
14.91 \\
4.89 \\
6.98 \\
0.11 \\
0.95 \\
0.00 \\
27.84\end{array}$ & $\begin{array}{r}71.12 \\
53.56 \\
17.56 \\
25.07 \\
0.40 \\
3.41 \\
0.00 \\
100.00\end{array}$ \\
\hline Average Parcel Numl & & 2.68 & & \\
\hline
\end{tabular}

Table 6. Crop pattern.

\begin{tabular}{lcr}
\hline Crops & Area sown (da) & \multicolumn{1}{c}{$\%$} \\
\hline Wheat & 9.68 & 48.89 \\
Barley & 2.97 & 15.00 \\
Oat & 0.27 & 1.36 \\
Corn & 1.22 & 6.16 \\
Other & 2.21 & 11.16 \\
Fallow & 2.36 & 17.42 \\
\hline Total Area Sown & 19.68 & 48.89 \\
\hline
\end{tabular}

Table 7. Livestock on farms.

\begin{tabular}{lc}
\hline Livestocks & Head \\
\hline Turkey & 4845 \\
Large ruminants & 3.38 \\
Cow & 1.51 \\
Heifer & 0.73 \\
Calf & 0.89 \\
Unweaned calf & 0.19 \\
Bullock & 0.05 \\
Small ruminant (sheep ve goats) & 0.32 \\
\hline
\end{tabular}


and as small ruminant, sheep and goats were kept. The number of these animals were 3.38 and 0.32 heads, respectively. These numbers were under Turkey average number (SIS, 2002).

Table 8. Agricultural machinery and equipments in farms.

\begin{tabular}{lc}
\hline Machinery and Equipments & Number \\
\hline Tractor & 0.43 \\
Drill & 0.22 \\
Trailer & 0.37 \\
Plough & 0.37 \\
Pulverizater & 0.31 \\
Harrow & 0.35 \\
Fertilizer distributor & 0.16 \\
Combine & 0.02 \\
Threshing machine & 0.06 \\
\hline
\end{tabular}

\section{Agricultural machinery and equipments}

$59.18 \%$ of contracted turkey breeding farms did not have tractors. Number of tractors per farm was 0.43 (see Table 8). Farms in the survey were not equipped enough agricultural machinery and equipment. As to given both tractor and other machinery equipment numbers, farms had a low level of agricultural machinery and equipments. This stems from farms' intensification on turkey breeding.

Annual cost and revenue status

In the contracted turkey farming, farms cover some of variable costs and all of the fixed costs during the production period. For this reason, in the calculation of farms' cost and revenues, costs covered by farms and revenues obtained by farms are only taken into consideration. According to research results, all of the costs related to chick provision, feed, vaccine and veterinarian services, $61.22 \%$ of medicine costs and $4.08 \%$ of tool-machine and fuel costs were covered by integrated firms. However, pre-production costs, temporary labor costs, heating and lightning costs were covered by farms.

Numbers related to costs were given on Table 9 . While the share of variable costs in total cost is $64.98 \%$, the share of fixed costs was $35.02 \%$. The bulk of variable costs belonged to heating costs (17.15\%). Illumination costs (16.49\%) and pad costs $(12.58 \%)$ fallowed heating costs in importance. On the other hand, the highest share in fixed costs belongs to poultry house depreciation $(10.57 \%)$. Permanent labor costs $(7.08 \%)$ and poultry house interest (6.67\%) fallow poultry house depreciation costs. Post-breeding average live weight was found $13.08 \mathrm{~kg}$. The cost of $1 \mathrm{~kg}$ live weight was $\$ 67.36$. Gross Production Value (GPV) obtained in one period was $2444.24 \$$ and in a year was $6428.35 \$$ year. While annual Net Income (NI) was $1293.91 \$$ year, annual Gross Income (GI) was $3083.18 \$ /$ year. Due to intensive turkey breeding system, investment costs were high. Since this increases the share of fixed costs in total costs, farms' incomes decrease.

Problems and farm managers views on contracted breeding

Time for dealing with contracted turkey breeding 
Table 9. Production cost and income of contracted turkey farms.

\begin{tabular}{|c|c|c|}
\hline Costs & $\begin{array}{c}\text { Value } \\
\$\end{array}$ & $\begin{array}{c}\text { Percentage } \\
\quad \%\end{array}$ \\
\hline \multicolumn{3}{|l|}{ 1. Pre-Production costs } \\
\hline - Disinfection (etalon) (quantity*price) & 38.29 & 1.96 \\
\hline$-\mathrm{Pad}(\mathrm{kg} * \$ / \mathrm{Kg})$ & 245.32 & 12.58 \\
\hline 2. Chick (number * \$/number) & - & - \\
\hline 3. Feed & - & - \\
\hline 4 Temporary labor (hour* $\$$ /hour) & 36.26 & 1.86 \\
\hline 5. Vaccine (dose* $\$ /$ dose) & - & - \\
\hline 6 Water $\left(\mathrm{m} 3 *{ }^{*} \mathrm{~m} 3\right)$ & 32.43 & 1.66 \\
\hline 7. Medicine & 79.39 & 4.07 \\
\hline 8. Veterinarian services & - & - \\
\hline 9. Heating & 334.57 & 17.15 \\
\hline 10. Illumination (kw x $\$ / k w)$ & 321.62 & 16.49 \\
\hline 11. Other & 148.65 & 7.62 \\
\hline \multicolumn{3}{|l|}{ 12. Interest of variable costs } \\
\hline (variable costs $/ 2 * \mathrm{r} \%)$ & 30.91 & 1.58 \\
\hline 13. Total Variable Costs (A) & 1267.45 & 64.98 \\
\hline 14. General management costs $(\mathrm{Ax} \% 3)$ & 38.02 & 1.95 \\
\hline 15. Permanent labor $(1 / 5)$ & 138.02 & 7.08 \\
\hline \multicolumn{3}{|l|}{ 16. Depreciation of poultry house : } \\
\hline (poultry hose value*depreciation rate)*1/2.63 & 206.19 & 10.57 \\
\hline $\begin{array}{l}\text { Poultry house interest: interest rate (r) (poultry hose } \\
\text { value* } 1 / 2 * 3 \%) * 1 / 2.63\end{array}$ & 130.00 & 6.67 \\
\hline \multicolumn{3}{|l|}{ 17. Water bowl, manger, etc. } \\
\hline Depreciation $=($ value $*$ depreciation rate $\%) * 1 / 2.63$ & 75.86 & 3.89 \\
\hline interest $=\left(\right.$ value $\left.^{1 / 2} \% 5\right) * 1 / 2.63$ & 94.83 & 4.86 \\
\hline 18. Total Fixed Costs (B) & 682.93 & 35.02 \\
\hline 19. Total Production Costs $(A+B)$ & 1950.38 & 100.00 \\
\hline Average Live Weight (kg/head) & 13.08 & \\
\hline Total Live Weight per farm (kg/farm) & 30087.00 & \\
\hline $1 \mathrm{~kg}$ live turkey cost $(\$ / \mathrm{kg})$ & 67.36 & \\
\hline Sale price $(\$ / \mathrm{kg})$ & 81.24 & \\
\hline Profit rate $\%$ & 20.61 & \\
\hline Gross production value (\$/farm) & 2444.24 & \\
\hline Net income/ period & 493.86 & \\
\hline Net income/year & 1293.91 & \\
\hline Gross Income/year & 3083.18 & \\
\hline
\end{tabular}

Table 10. Time for dealing with contracted turkey breeding.

Time for dealing with contracted breeding in other subject (year) $\quad 10.19$

Time for contracted turkey breeding (year) $\quad 2.63$

Time for contracted poultry farming (\%) 65.31 
Table 11. Factors leading to contracted turkey breeding. : .

\begin{tabular}{lrr}
\hline Effective factors & Rate (\%) \\
\hline Price and sale guarantee & 38.78 \\
Input provision & & 12.24 \\
Technical assistance & 2.04 \\
Contracted breeding experience & & 6.12 \\
Other (firm reliability, profitable than chicken farming and & & \\
cattle breeding, not having another alternative, trial, great & \\
future of contracted turkey breeding) & & 10.20 \\
\hline
\end{tabular}

Time for dealing with contracted turkey breeding was on the average 2.63 years. As to research results, none of the farms dealt with turkey breeding before and this was their first activity on this matter. On the other hand, results show that $63.31 \%$ of them dealt with contracted chicken farming before and $10.19 \%$ of them dealt with contracted breeding in other agricultural subject.

Factors leading to contracted turkey breeding

According to research results, while $38.78 \%$ of farms stated that price and sale guarantee were the important factors, $12.78 \%$ stated that input provision was an important factor. Given economic crises in recent years in Turkey, these factors were reasonable.

Problems of contracted turkey breeding

As to research results, $71.43 \%$ of farms stated that the most important problem was price determination which determined by firms. In addition, delayed payments, lack of government audit, high costs, and lack of infrastructure were the other important factors.

Table 12. Main problems of contracted turkey breeding.

\begin{tabular}{lc}
\hline Problem & Rate (\%) \\
\hline Determination of price by firms & 71.43 \\
Delayed payments & 4.08 \\
Biased contract & 2.04 \\
Lack of government audit & 2.04 \\
Other (high costs, infrastructure problems, lack of support) & 8.16 \\
\hline
\end{tabular}

\section{Practices and expectations in contracted turkey breeding}

As to research results, $75.51 \%$ of contracted turkey farms did not read the contract made with the firm (see Table 13). $91.84 \%$ of farms stated that they have no right objecting to the contract provisions. However, $81.63 \%$ of firms fulfilled provisions in the contract. While the rate of farms received expected benefits from contracted turkey breeding is $57.14 \%$, the rate of rest was $42.86 \% .91 .84 \%$ of farms welcome integrated firms' suggestions.

$75.51 \%$ of farms wanted to be organized in contracted turkey breeding and $63.33 \%$ of them wanted to contract made between their representative organization and integrated firm. As shown on Table 4. Farms' membership to any agricultural organization was not at enough level. However, those organizations provides services in plant production, 
Table 13. Practices and expectations in contracted turkey breeding.

\begin{tabular}{|c|c|c|c|}
\hline Practices and expectations & $\%$ & $\%$ & $\%$ \\
\hline Did you read the contract before signing? & Yes $(75.51)$ & No (24.49) & \\
\hline $\begin{array}{l}\text { Do you have any right to object the } \\
\text { contract? }\end{array}$ & Yes $(8.16)$ & No (91.84) & \\
\hline Does the firm fulfill the contracts' & & & \\
\hline provisions? & Yes (81.63) & No $(18.37)$ & \\
\hline Do you receive expected benefits? & Yes $(57.14)$ & No $(42.86)$ & \\
\hline Do you welcome firms' suggestions? & Yes $(91.84)$ & No (4.08) & Sometimes (4.08) \\
\hline Do you want to organized as farmer? & Yes (75.51) & No (16.33) & No idea $(8.16)$ \\
\hline $\begin{array}{l}\text { Do you want the contract should be } \\
\text { signed by a breeder organization? }\end{array}$ & Yes $(63.70)$ & $\begin{array}{l}\text { No (26.53) } \\
\text { Farmer }\end{array}$ & No idea $(10.20)$ \\
\hline Which organization? & MARA*(42.42) & Organiz. (30.30) & \\
\hline $\begin{array}{l}\text { Are you satisfied with income obtained } \\
\text { from contracted turkey breeding? } \\
\text { Do you think of continuing contracted } \\
\text { turkey breeding in the future? }\end{array}$ & Yes ( 36.73$)$ & No $(63.27)$ & \\
\hline
\end{tabular}

* Ministry of Agriculture and Rural Affairs

breeders want organization in contracted turkey breeding activity. $42.42 \%$ of farms stated that organization at the MARA level was enough. On the other hand, $30.30 \%$ of farms stated that organization should be at farmer level. One of the most important evidences of survey was that $63.27 \%$ of breeders were not satisfied with income obtained from contracted turkey breeding. In spite of this, $83.67 \%$ of them told that they would continue contracted turkey breeding. Input provision and marketing guarantee play an important role their continuation in contracted turkey breeding.

\section{CONCLUSIONS AND RECOMENDATIONS}

In the studied farms the average net income from turkey breeding was $1293.91 \$ /$ year and gross income was $3083.18 \$ /$ year as seen Table 9 . It was determined that the adequate income for farms was $2740 \$$ in 1984 in Turkey according to law 3083, Agricultural Reform on Regulations for Irrigated Land, published in Official Newspaper in December 1st, 1984 (Anonymous 1984). This income was calculated as $3500 \$$ for 2002 year when it was calculated with wholesale price index for Turkey. According to this value, obtained net income from contracted turkey breeding was covered $37 \%$ and gross income was covered $88 \%$ of income that was adequate to subsist. According to this values, obtained income for farms from contracted turkey breeding was not enough level. But, in the recent years there has been economic difficulties in Turkey depend on the economic crisis. As taking into consideration this economic crisis, it could be said that the obtained income for farms from contracted turkey breeding was important to survive and also sustainable production. On the other hand, turkey breeding was not only income resource for studied farms, but also they were engaged plant production (Table 5), large and small animal breeding (Table 7). To increase income from contracted turkey 
breeding, the fallowing recommendations could be make:

- The bulk of variable costs belonged to heating, lighting and pad costs fallowed in importance (Table 9). To decrease these costs, to educate farmers on care and management could be play a role. As seen Tables 2 and 3, it could be said that whether education level, regular newspaper reading or watching TV and agricultural programs in studied farms was higher than the average farm in Turkey. Thus, some educational programs, like as care and management of turkey breeding, directed farm manager and/or families by firms, government organizations, universities could be very beneficial.

- In the studied farms, the highest share in fixed costs belonged to poultry house depreciation and poultry house interest. The important reason for this, in order to these farms were intensive farms and new established, investment cost was high. In the long run, the net margin will have being getting higher. On the other hand, another important reason, they have no right for signing the contract with firms. They have been signing contracts individually against the big firms. Farmers organization or cooperation could be a good solution to solve this kind of problems. If a part of the investment cost is covered by firm, the fixed cost that all belong to farmers would decreased, and it would be encourage for other low income farms and unemployed families to begin contract farming.

- In the fixed cost, permanent labor cost was also high level. To decrease permanent labor cost, to use family labor could play an important role. As seen Table 1 whether young population or young labor capital were high. To use family labor would not only decrease fixed cost but also use idle labor in the family.

- The contracted farms had some problems related contracts with integrated firms and many of farms were not satisfied obtained income. But, farmers stated that they would like to continue production because of the marketing guarantee and input assurance, though. Farmer cooperation or any organization could be beneficial for more profitable production and increased number of contracted turkey farming.

- If the above recommendations and the policies that would solve above problems are taken into consideration, contracted turkey breeding would be a good alternative to cover meat demand in Turkey and also to increase farm income.

\section{REFERENCES}

Hackner, J. 2001 Vertical Integration and Competition Policy, Department of Economics, Stockholm University, Sweden

Hart, O. and J. Tirole 1990 Vertical Integration and Market Foreclosure, Brookings Papers on Economic Activity, Special Issue, 205-276

Ordever J. A., G. Saloner and S. C. Salop 1990 Equeblirium Vertical Foreclosure, American Economic Review, 80: 127,142 .

Ozcelik, A., A. Turan and H. Tanrıvermis 1999 Türkiye'de Tarmın Pazara Entegrasyonunda Sözleş meli Tarm ve Modelin Sürdürülebilir Kaynak Kullanımı ile Üretici Geliri Üzerine Etkileri, Tarımsal Ekonomi Araş tırma Enstitüsü Yayınları, Yayın No: 14, Ankara

Rehber, E. 2000 Vertical Coordination in the Agro-Food Industry and A Contract Farming: A Comparative Study of Turkey and the USA, Food Market Policy Center, Research Report No: 52, Department of Agriculture and Resource Economics, University of Connecticut, USA

Riordan, M. H. 1998 Anticompetitive Vertical Integration, by a Dominant Firm, American Economic Review, 88: $1232-1248$

Salingner, M. A. 1988 Vertical MErgers and Market Foreclosure, Quaertly Jourmal of Economics, 103: 
345-356

SIS 2001 Population Census in 2000 http:www.die.gov.tr

SIS 2002 Agricultural Census in 2001 http:www.die.gov.tr

Warning, M. and K. Nicel 2000 The Social Performance and Distributional Consequences of Contract Farming: An Empricial analysis of the Aracbide de Bouche Program in Senegal, University of Puget Sound and United State Department of Agricultural Economic Research Service 